\title{
Evolution of self-care dependent individuals admitted to the National Network for Integrated Continuous Care
}

Evolução das pessoas dependentes no autocuidado acompanhadas na Rede Nacional de Cuidados Continuados Integrados

Evolución de las personas dependientes en el autocuidado acompañadas en la Red Nacional de Cuidados Continuos Integrados

Fernando Alberto Soares Petronilho*; Cidália Maria Batista Coutinho Pereira**; Ana Isabel da Costa Magalhães***;

Dora Marina Freitas Carvalho ${ }^{* * * *}$; Jorge Miguel Costa Oliveira ${ }^{* * * * *}$; Paula Ricardina Costa Vieira de Castro ${ }^{* * * * * *}$

Maria Manuela Pereira Machado*******

\section{Abstract}

Background: The National Network for Integrated Continuous Care (NNICC) emerged as a response to the increasing aging of the Portuguese population and the consequent increase in the number of self-care dependent individuals.

Objectives: To assess the potential for the recovery of autonomy, the evolution of bodily processes impairment, and the level of self-care dependence among dependent individuals admitted to the NNICC.

Methodology: A descriptive and exploratory study was conducted using a convenience sample of 891 dependent individuals from 10 NNICC care units within the area of influence of a Local Coordination Team in the region of Minho, Portugal. Results: The results showed a low to moderate potential for the recovery of autonomy. There was a positive evolution in bodily processes impairment and in the level of self-care dependence. The greater potential for the recovery of autonomy is associated with a lower level of bodily processes impairment and a higher self-care independence.

Conclusion: The study reveals effective health gains in the health condition of dependent individuals admitted to the NNICC, within its different types of care, which demonstrates its usefulness.

Keywords: personal autonomy; body constitution; self-care; long-term care

\section{Resumo}

Enquadramento: A Rede Nacional de Cuidados Continuados Integrados surgiu como resposta ao crescente envelhecimento da população portuguesa e ao consequente aumento do número de pessoas dependentes no autocuidado. Objetivos: Avaliar o potencial de reconstrução de autonomia, e a evoluçáo do compromisso nos processos corporais e da dependência no autocuidado das pessoas dependentes admitidas na Rede.

Metodologia: Estudo descritivo e exploratório, com uma amostra de conveniência constituída por 891 pessoas dependentes, realizado em 10 prestadores de cuidados da Rede da área de abrangência de uma Equipa Coordenadora Local da região Minho de Portugal.

Resultados: O potencial de reconstrução de autonomia situa-se entre reduzido a moderado. Verificou-se uma evolução positiva no compromisso nos processos corporais e no nível de dependência no autocuidado. Maior potencial de reconstrução de autonomia está associado a menor compromisso nos processos corporais e a maior independência. Conclusáo: $\mathrm{O}$ estudo revela ganhos em saúde efetivos na condição de saúde das pessoas dependentes acompanhadas nas diferentes tipologias de cuidados da Rede, o que demonstra a sua utilidade.

Palavras-chave: autonomia pessoal; constituiçấo corporal; autocuidado; assistência de longa duração

*Ph.D., Adjunct Professor, University of Minho, 4710-057, Braga, Portugal [fpetronilho@ese. uminho.pt]. Contribution to the article: original idea, statistical treatment, discussion of results, and article elaboration. Address for correspondence: Travessa da Quinta, n²2, 4715-038, Braga Portugal.

SC. Head Nurse. Health Center of Cabeceiras de Basto, 4860-339. Cabeceiras de Basto, Por tugal [cidata
collection.

****RN. Health Center of Cabeceiras de Basto, 4860-339. Cabeceiras de Basto, Portugal [anisabelmag@gmail.com]. Contribution to the article: original idea and data collection.

***** Head Nurse, Centro Social e Paroquial de Sta Eulália de Nespereira, 4810-507, Guimarães, Portugal [doracarvalho@gmail.com]. Contribution to the article: data collection.

****:Head Nurse, Santa Casa da Misericórdia de Vizela, 4815-901, Vizela, Portugal [jorgeoliveira@uccizela.com]. Contribution to the article: data collection.

******Norse Specialist, Health Center of Fafe, 4820-273, Fafe, Portugal [eccifafe@gmail.com] Contribution to the article: data collection,
$* * * * * * * *$ Ph. D. Adjunct Professor, School gal [mmachado@ese.uminho.pt].Contribution to the article: article revision.

\section{Resumen}

Marco contextual: La Red Nacional de Cuidados Continuados Integrados surgió como respuesta al creciente envejecimiento de la población portuguesa y al consiguiente aumento del número de personas dependientes en el autocuidado.

Objetivos: Evaluar el potencial de reconstrucción de la autonomía, y la evolución del compromiso en los procesos corporales y de dependencia en el autocuidado de las personas dependientes admitidas en la Red.

Metodología: Estudio descriptivo y exploratorio, con una muestra de conveniencia constituida por 891 personas dependientes, realizado en 10 prestadores de cuidados de la Red del área de cobertura de un equipo coordinador local de la región del Miño de Portugal.

Resultados: El potencial de reconstrucción de la autonomía se sitúa entre reducido y moderado. Se verificó una evolución positiva en el compromiso en los procesos corporales y en el nivel de dependencia en el autocuidado. Un mayor potencial de reconstrucción de la autonomía se asocia con un menor compromiso en los procesos corporales y una mayor independencia.

Conclusión: El estudio revela beneficios efectivos en la salud de las personas dependientes acompañadas en las diferentes tipologías de cuidados de la Red, lo que demuestra su utilidad.

Palabras clave: autonomía personal; constitución corporal; autocuidado; cuidados a largo plazo 


\section{Introduction}

In recent decades, Portugal has seen a cumulative effect of the reduction in mortality and birth rates, which has resulted in the progressive aging of the population and the increase in the number of dependent individuals. According to the Portuguese Observatory of Health Systems (Observatório Português dos Sistemas de Saúde [OPSS], 2015), there are approximately 110,000 self-care dependent individuals. Health policies based on cost containment principles, as well as humanistic principles, point to the integration of dependent individuals into the family context ( $\mathrm{Ri}$ beiro, Pinto, \& Regadas, 2014).

For the past decade, long-term care has improved and progressed through the implementation of the Rede Nacional de Cuidados Continuados Integrados (National Network for Integrated Continuous Care, NNICC). In a paradigm shift, the objectives set out for the functioning of NNICC focus on self-care as the most relevant dimension of the citizens' health, both at the social and political levels. According to Petronilho, Pereira, and Silva (2017), at hospital discharge, $58.6 \%$ of the dependent persons returned home, whereas $28.1 \%$ were admitted to NNICC units.

The official monitoring reports on the functioning of the NNICC lack outcome indicators that reflect the health gains of dependent persons during their stay at NNICC care units, namely gains in self-care dependence. This fact served as basis for the development of this study in inpatient units, namely Unidades de Convalescência (Convalescence Units, CUs), Unidades de média duração e reabilitaçâo (Medium-term and Rehabilitation Units, MTRUs), and Unidades de longa duração e manutenção (Long-term and Maintenance Units, LTMUs), and in home care responses, that is, Equipas de cuidados continuados integrados (Integrated Continuous Care Teams, ICCTs). The following objectives were set out: i) to assess the potential for the recovery of autonomy; ii) to assess the evolution of bodily processes impairment; and (iii) to assess the evolution of the level of autonomy in self-care dependent persons in each type of health care unit.

It should also be noted that this study is part of a wider research project developed at the Nursing Research Center at the School of Nursing of the University of Minho.

\section{Background}

European countries currently face a demographic transition and consequent epidemiological transition, characterized by the significant aging of the population. In Portugal, according to the 2011 census, the aging rate was 129 , which is estimated to rise to 271 by 2060 (Instituto Nacional de Estatística, 2011). Health-related research on the aging phenomenon points to an expected positive correlation between age and self-care dependence as a result of the functional decline (OPSS, 2015). This evidence has represented a challenge for society to the extent that innovative responses are necessary, both in the models of care delivery and social support organization and in family organization models, by focusing on an effective articulation between professional support, individuals' health status improvement, and the appropriate role of family members as caregivers.

Empirical studies in the health area, which were recently conducted in the regions of Lisbon (Costa, 2013), Porto (Filipe, 2015; Gonçalves, 2013; Ribeiro et al., 2014), and Minho (Petronilho, 2013), allowed for the production of knowledge on the Portuguese reality regarding the magnitude of the phenomenon of self-care dependence and families with dependent persons. In Portugal, there are approximately 4 million traditional households, of which about $2.9 \%$ have a dependent relative (OPSS, 2015). A high number of these dependent people are bedridden, accounting for about 48,000 cases. Being bedridden indicates an extremely vulnerable condition which is characterized by high levels of dependence and physical and mental impairment (e. g., the existence of pressure ulcers, respiratory impairment, cognitive impairment).

Self-care dependent persons are submitted to criteria for NNICC referral to ensure quality in the delivery of long-term integrated care and social support.

According to the International Council of 
Nurses, self-care is a self-performing activity with specific characteristics: "taking care of what is needed to maintain oneself, keep oneself going and handle basic individual and intimate necessities and activities in daily life" (Conselho Internacional de Enfermeiros [CIE], 2005, p. 46). Dependence is an individual health condition which is characterized by limitations in physical, psychic, or intellectual autonomy resulting from acute or chronic illness, cognitive impairment, trauma or even absent or insufficient family or other type of support, preventing the individual from being able to independently perform activities of daily living (Decreto-lei $n^{\text {o }} 101 / 2006$ de 6 de junho). When referring to self-care, this concept is clearly associated with another key concept in the evolution of a person's health condition: the potential for the recovery of autonomy (PRAut), which is influenced by physical and mental processes, the existence of chronic illness, age, level of awareness, attitude towards life, meanings assigned to and involvement in the process of autonomy recovery. In addition, it is also influenced by external factors such as family processes, the community, society, and the therapeutic nursing care (Koç, 2015; Maciel, 2013; Petronilho, 2013; Sacco-Peterson $\&$ Borell, 2004). The study conducted by Petronilho (2013) shows that people who had a more favorable evolution in the level of self-care dependence had a higher PRAut and were admitted to NNICC units.

Care delivery in the NNICC is generally structured around two axes: one results from the dependent person's level of dependence and potential for recovery of autonomy; the other arises from the need to empower family caregivers to care for their relatives. The mission of the NNICC focuses on 1) promoting integrated health and social support interventions; 2) providing care centered on dependence (to the detriment of disease); and 3 ) increasing home care provided by ICCTs. The most recent NNICC monitoring report shows overall health indicators, namely process indicators such as the number of vacancies per type of care, referral rates, occupancy rates per health care unit, mean delays, and financial implementation, which, although important, focus heavily on the conditions to access the NNICC (Administração Central do Sistema de Saúde [ACSS], 2015). However, we believe that it would be important to produce clinical indicators that would enable the assessment of the impact of the care provided by the NNICC on the health status of dependent persons and their families. Therefore, the production of outcome indicators (e.g., gains in the level of self-care dependence and in the effectiveness of the prevention of complications) should be a priority with a view to monitoring the quality of care provided by NNICC units and support the clinical and strategic decision-making in health-related policies. This study aims at contributing to the production of these outcomes.

\section{Research questions}

What is the self-care dependent person's potential for the recovery of autonomy at the time of admission to the NNICC?

How do people admitted to the NNICC evolve in terms of bodily processes impairment and level of self-care dependence between admission and clinical discharge?

\section{Methodology}

A quantitative, descriptive, and exploratory study was conducted with two assessment moments (admission and clinical discharge) to measure the evolution of the sampled participants' health condition.

The study was conducted in 10 NNICC health care units within the area of influence of a Local Coordination Team of Minho, Portugal: two CUs, one MTRUs, three LTMUs, and four ICCTs.

The sample consists of all dependent persons admitted to NNICC during the period of time established for data collection (1 year) - between 01/03/2014 and 28/02/2015. The sample was selected using a non-probability convenience sampling method. A total of 891 cases were assessed on admission and 601 cases at clinical discharge, and are distributed by the four types of care delivery (Table 1). 
Table 1

Distribution of the dependent persons who were assessed on admission and at clinical discharge

\begin{tabular}{clcc}
\hline No. & Type of health care unit & $\begin{array}{c}\text { Admission No. } \\
(\%)\end{array}$ & $\begin{array}{c}\text { Clinical } \\
\text { discharge } \\
\text { No. (\%) }\end{array}$ \\
\hline 2 & Convalescence Unit (CU) & $265(29.7)$ & $233(38.8)$ \\
1 & Medium-term and Rehabilitation Unit (MTRU) & $160(18)$ & $134(22.3)$ \\
3 & Long-term and Maintenance Unit (LTMU) & $241(27)$ & $101(16.8)$ \\
4 & Integrated Continuous Care Teams (ICCTs) & $225(25.3)$ & $133(22.1)$ \\
\hline
\end{tabular}

The sample evolution throughout the data collection period, including the reasons for the decrease

in the number of assessed cases between admission and clinical discharge, is shown in Figure 1.

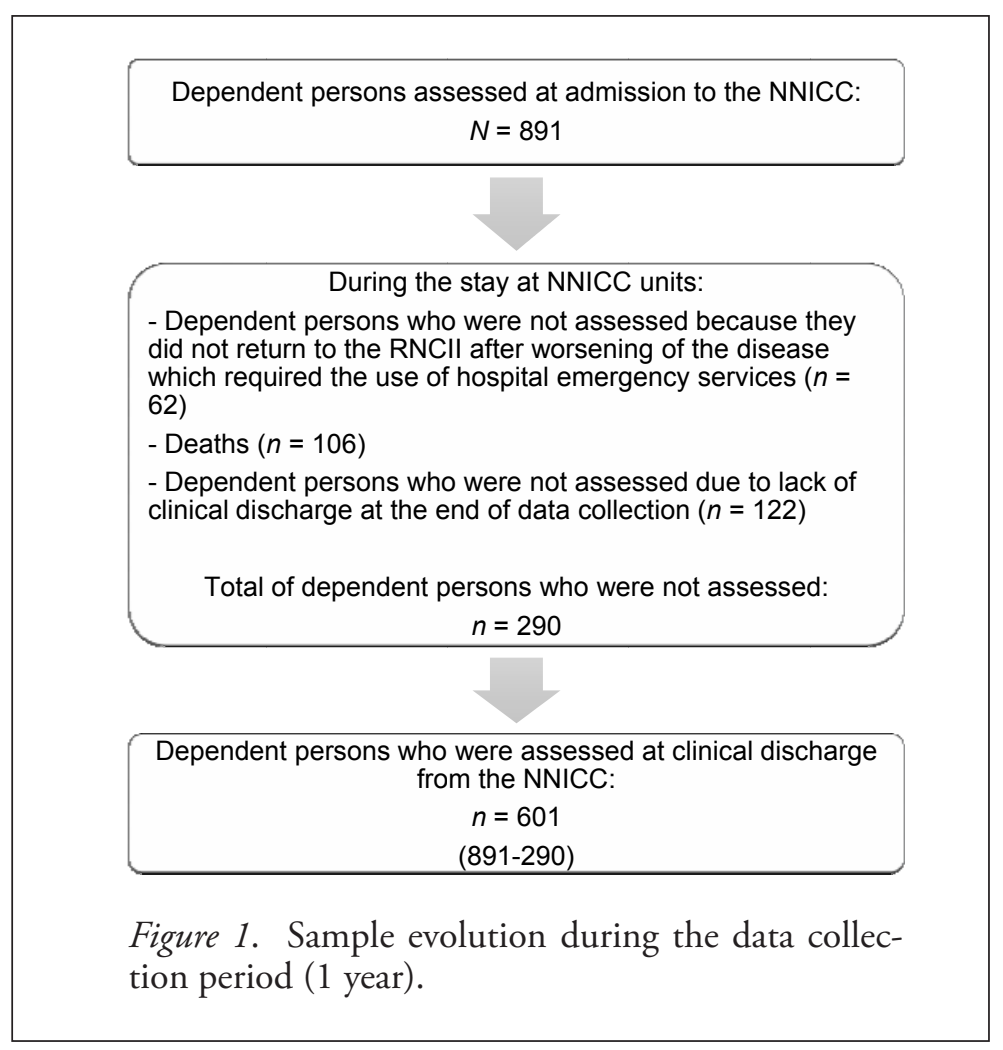

Data were collected by the nursing teams of the NNICC care units where the study was conducted. An assessment tool was specifically designed and applied for this research study: Profile of Dependent Persons and Families Integrated into NNICC Care Units (Perfil dos Dependentes e Familias Integrados nos Prestadores de Cuidados da RNCCI).

\section{Potential for the recovery of autonomy (PRAut)}

This is a dimension of the scale which was designed and validated by Petronilho (2013) and applied at the time of admission to the NNICC. The total score results from the sum of seven items: client's identification of the changes in his/her health 
status; client's willingness to learn; client's belief about his/her ability to recover; client's reported desire to become more independent; motivation, proactivity, and involvement of the client in the learning process; client's cognitive skills; client's physical skills (e.g., muscle strength).

Each item is scored from 1 to 4 (score 1 - no potential; score 2 - reduced potential; score 3 moderate potential; and score 4 - high potential). Each assessed person can have a minimum overall score of 7 (no potential) and a maximum overall score of 28 (bigh potential). The application of the scale $(n=891)$ showed that it has an excellent internal consistency, with a Cronbach's alpha coefficient $(\alpha)$ of 0.975 .

\section{Bodily processes impairment (BPImp)}

This dimension characterizes the dependent person according to whether or not there are actual or potential physiological changes in 14 foci of attention (pressure ulcer, risk of joint stiffness, joint stiffness, risk of maceration, maceration, risk of dehydration, dehydration, ineffective expectorate pain, ventilation/elimination ostomy, decreased muscle strength, balance while sitting, balance while standing, risk of fall), to which a clinical judgment is assigned: yes (score 1) and no (score 2). Each assessed person can have a minimum overall score of 14 (maximum BPImp) and a maximum overall score of 28 (absence of BPImp). Therefore, the higher the score, the better is the dependent person's health condition in terms of physical processes.

\section{Level of self-care dependence ( $\mathrm{LScD}$ )}

This scale is scored using 10 domains of self-care as defined by the International Classification for Nursing Practice $\left(\mathrm{ICNP}^{\circledR}\right.$ ), version 1: self-bathing, self-dressing/undressing, self-grooming, self-toileting, self-feeding, self-lifting, self-turning, self-transferring, walking, and taking medication (CIE, 2005). Each domain is scored between 1 and 4 (score 1 totally dependent; score 2 - requires help from others; score 3 - requires devices; and score 4 independent). Each assessed person can have a minimum overall score of 10 (totally dependent) and a maximum score of 40 (independent). This scale has shown an excellent internal consistency, both at the time of admission $(n=891)$ and clinical discharge $(n=601)$, with a Cronbach's alpha coefficient $(\alpha)$ of 0.965 and 0.983 , respectively.

Prior to data collection, the dependent people or family members were asked to give their informed consent to participate voluntarily in the study. The purpose of the study was explained and the confidentiality of both the answers and clinical judgments was ensured. All ethical and legal principles were followed. The study was approved by the Health Research Ethics Committee of the Regional Health Administration of the North Region (Opinion no. 14/2014). The descriptive and inferential statistical analysis was performed using the Statistical Package for the Social Sciences ${ }^{\oplus}$ (SPSS), version 23.0. The statistical significance level was set at 5\%.

\section{Results}

Most of the dependent people were women $(56.6 \%)$, married (46\%), despite a significant number of widowed people (38.8\%). The mean age was 76.7 years, but the majority of participants were aged $\geq 80$ years $(50.2 \%)$. Most of them had basic education $(50.6 \%)$ or were illiterate $(42.6 \%)$, and were either pensioner or retired $(60.4 \%)$. The major cause leading to dependence was an acute disease (44.6\%). In most cases, the person became dependent in a sudden way $(56.6 \%)$; the mean length of dependence before referral to the NNICC was 1.5 years, and approximately $2 / 3$ of the sample were already dependent prior to the health event leading to NNICC referral (66.9\%). The majority of dependent persons were referred by clinical discharge planning teams (73\%). On average, dependent persons stayed in the NNICC for 112 days, in the case of LTMUs, and for 91 days, in the case of ICCTs. Among the sampled dependent persons, $11.9 \%$ died and $7 \%$ did not return to the NNICC afte disease worsening which required the use of hospital emergency services.

\section{Potential for recovery of autonomy (PRAut)}

The results showed a low to moderate PRAut (overall mean $=16.8$ ). As Figure 2 shows, dependent persons admitted to CUs had a higher PRAut (mean $=20.3$ ), whereas those admitted to LTMUs had a lower PRAut (mean $=13.4$ ), [Admission: $F(3.887)=59.1, p<0.001$ ]. 


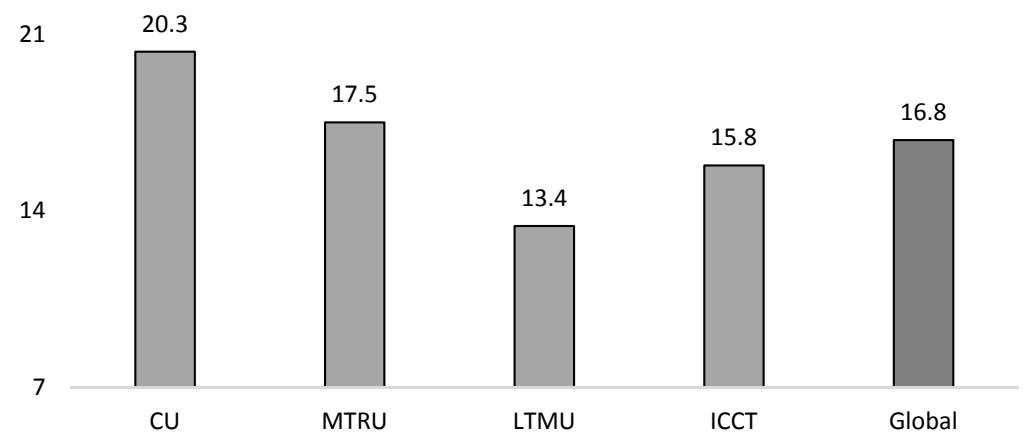

Figure 2. Potential for recovery of autonomy at admission, per type of care unit.

Evolution of bodily processes impairment (BPImp)

A total of 891 cases on admission and 601 cases at clinical discharge were assessed regarding the level of BPImp. A positive evolution in the level of BPImp was observed between admission and discharge per type of care unit (Figure 3) and in the total score [Admission: overall mean $=21.4$; Discharge: overall mean $=23.2 ; t(601)=-16.2, p<0.001]$. The one- way analysis performed to compare the four types of care showed that the dependent persons admitted to CUs had lower BPImp, both on admission [mean $=22.4 ; F(3.887)$ $=40.5, p<0.001]$ and at clinical discharge $[$ mean $=24.4 ; F(3.598)=39.7, p<0.001]$. In both assessment moments, the dependent persons admitted to LTMUs had a higher level of BPImp (Admission: mean $=20.3$; Discharge: mean $=21.7)$.

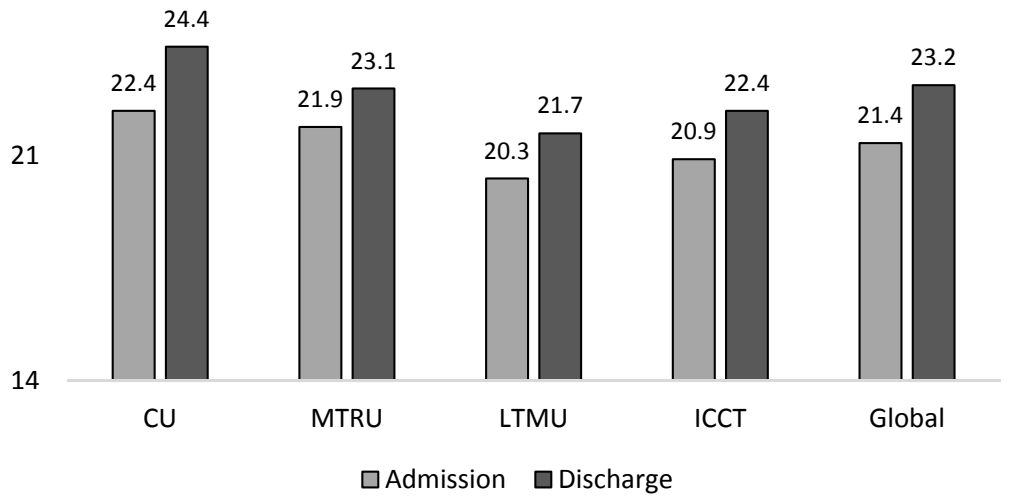

Figure 3. Evolution of bodily processes impairment, per type of care unit. 
Evolution of the level of self-care dependence ( $\mathrm{LScD}$ )

A total of 891 cases on admission and 601 cases at clinical discharge were assessed regarding the $\mathrm{LScD}$. The results showed a positive evolution in the LScD between admission and clinical discharge per type of care unit (Figure 4) and in the total score. The overall level of dependence on admission ranged between totally dependent and requires help from others (overall mean $=18.6$ ) and between requires help from others and requires devices at clinical discharge (overall mean $=26) ; t(600)=$ $-20.4, p<0.001$. The comparison of the evolution of the $\mathrm{LScD}$ between the four types of care unit showed that the dependent persons admitted to CUs were less dependent on both assessment moments and had a more positive evolution, with the scores ranging between requires help from others and requires devices on admission ( $F(3.887)=53.8, p<0.001$, and between requires devices and independent on clinical discharge $($ mean $=33.4) ; F(3.597)=90.3$, $p<0.001$. The dependent persons admitted to LTMUs, which include more people who are more dependent people both at admission and clinical discharge, had scores ranging between totally dependent and requires help from others and had a less positive evolution (Admission: mean $=14.5$; Discharge: mean $=17.4)$.

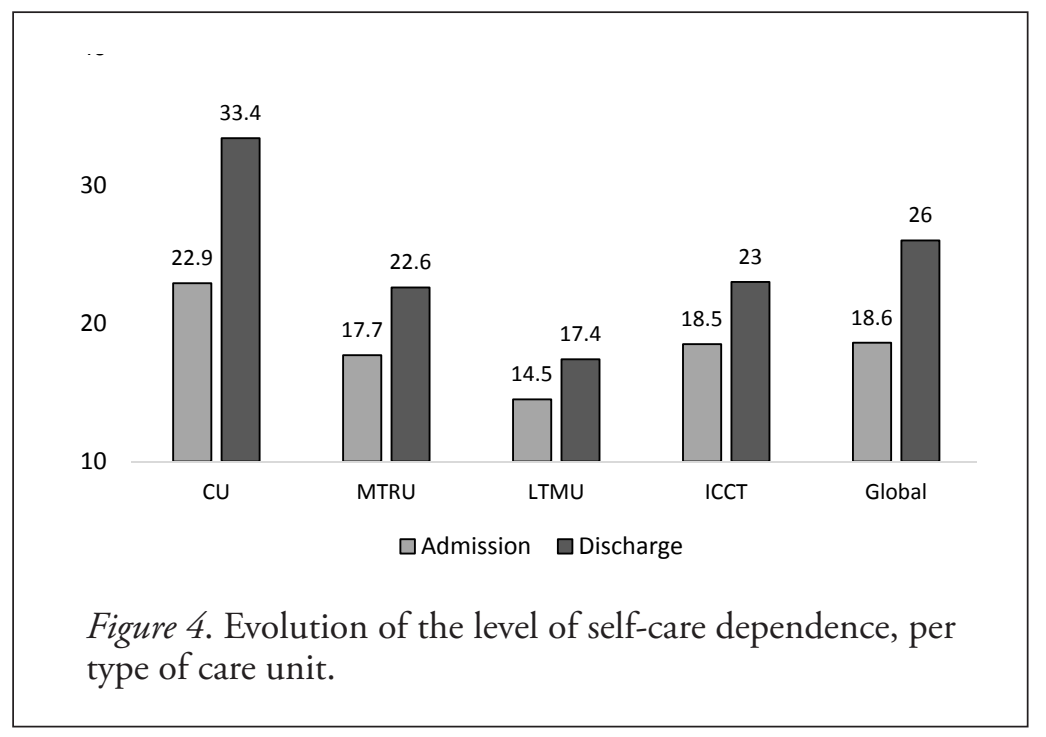

With regard to the correlation between the main variables under analysis, the following statistically significant correlations were observed:

A higher PRAut on admission was associated with: younger age $(r=-0.240, p<0.001)$; less time of dependence prior to NNICC admission $(r=-0.200, p<0.001)$; reduced length of stay $(r=-0.234, p<0.001)$; fewer episodes of disease worsening $(r=-0.131, p=0.001)$; a lower level of BPImp on admission $(r=0.636$, $p<0.001)$; a lower level of FImp at clinical discharge $(r=0.600, p<0.001)$; and a more positive evolution of $\mathrm{LScD}$ between admission and clinical discharge $\left(r_{s}=0.341, p<0.001\right)$.
A lower score in the $\mathrm{LScD}$ on admission (in individuals who are more dependent) was associated with: older age $(r=-0.289$, $p<0.001)$; lower PRAut on admission $(r=$ $0.755, p<0.001$ ); longer time of dependence prior to NNICC admission $(r=-0.150, p<$ $0.001)$; increased length of stay $(r=-0.269, p$ $<0.001)$; more episodes of disease worsening $(r=-0.159, p<0.001)$; and a higher level of BPImp on admission $(r=0.683, p<0.001)$. A lower score in the $\mathrm{LScD}$ at clinical discharge (in individuals who are more dependent) was associated with: older age $(r=-0.312$, $p<0.001)$; lower PRAut on admission $(r=$ $0.709, p<0.001)$; longer time of dependence 
prior to NNICC admission $(r=-0.198, p<$ $0.001)$; increased length of stay $(r=-0.326$, $p<0.001)$; more episodes of disease worsening $(r=-0.150, p<0.001)$; and a higher level of FImp at clinical discharge $(r=$ $0.808, p<0.001)$.

A more positive evolution in the $\mathrm{LScD}$ between admission to the NNICC and clinical discharge was associated with less time of dependence prior to NNICC admission $\left(r_{s}=-0.251, p<0.001\right)$.

\section{Discussion}

The sample sociodemographic characterization in this study is consistent with other studies on dependent people that have been recently conducted in Portugal (Costa, 2013; Filipe, 2015; Gonçalves, 2013; Petronilho, 2013). The sample of this study is mostly composed of older people, which confirms the expected correlation between older age and the increased level of self-care dependence. Most of the dependent persons were widowed women, which confirms the trend of "feminization" of aging in developed countries (Paúl, 2012). The percentage of deaths $(11.9 \%)$ is slightly higher than the national percentage in the same time period (11.4\%; ACSS, 2015).

In general, individuals admitted to the NNICC have a low to moderate potential for recovery of autonomy. Older age, associated with sudden acute illness as the major cause leading to dependence, and the fact that most people were already dependent prior to NNICC admission, which led to a further deterioration of the person's physical and mental condition, may have contributed to the obtained results (Sacco-Peterson \& Borell, 2004). This study also showed that individuals admitted to CUs and MTRUs have a greater potential for recovery of autonomy when compared to those admitted to LTMUs and ICCTs, which is in line with the criteria for referral to each type of care unit.

These results cannot be dissociated and are consistent with the results obtained on the level of self-care dependence and functional impairment: the greatest potential for the recovery of autonomy is associated with a lower level of functional impairment and higher self-care independence. Costa (2013) and Gonçalves (2013) obtained similar results in studies with samples of dependent persons in home care settings.

A detailed analysis and comparison of the results obtained across the different types of care units showed that the dependent persons admitted to CUs and MTRUs have a greater potential for recovery of autonomy, higher self-care independence, and a lower level of functional impairment than those admitted to LTMUs and ICCTs. These results are confirmed by the longitudinal study conducted by Petronilho (2013), in which a significant number of individuals with a positive evolution in the level of care dependence over a 3-month period after hospital discharge had been referred to CUs and MTRUs. The criteria for referral to the NNICC, as described in Decree-Law no. $101 / 2006$, contribute to this evidence to the extent that both CUs and MTRUs aim at providing care to people experiencing a temporary loss of autonomy and presenting a potential for recovery. LTMUs focus on the temporary or permanent care delivery to highly vulnerable dependent persons with a chronic illness. In these units, the main goal of the institutionalization is to manage dependence, prevent complications in bodily functions, provide comfort, well-being, and improve the quality of life. In this sense, people admitted to CUs and MTRUs are expected to have a greater health potential than those referred to LTMUs. The results obtained in ICCTs will be discussed separately since these teams provide care in home care settings.

As regards the assessment of the dependent person's health condition and, consequently, the identification of an adequate type of NNICC care unit, the results of this study confirm the adequacy of the clinical judgment of the multidisciplinary teams involved in the referral process. The studies conducted by Koç (2015), Maciel (2013), Petronilho (2013), and Sacco-Peterson and Borell (2004) corroborate these results. Dependent people who show a more positive evolution in the recovery of autonomy are 
more involved, have better decision-making skills and access to social resources, have fewer chronic illnesses, and tend to adhere better to the treatment regimen prescribed by health professionals.

The results obtained in the ICCTs show a positive evolution in the dimensions under analysis, as in the other types of care units; however, these results are more similar to those obtained in the MTRUs. The referral to an ICCT has the mandatory criterion of identifying a family caregiver who, despite not being a health professional, is a key resource in caring for the dependent person and keeping him/her at home (Schumacher, Stewart, Archbold, Dodd, \& Dibble, 2000; Shyu, Chen, Chen, Wang, \& Shao, 2008).

This study shows that dependent individuals admitted to ICCTs and MTRUs have similar results. The study conducted by Filipe (2015) in four ICCTs in the metropolitan region of Porto concluded that home care delivery is more economically sustainable than care delivery in institutional settings. In Portugal, families prefer to keep the dependent person at home, and institutionalization is only seen as the solution in cases of absent or insufficient formal and informal support (Gonçalves, 2013; Machado, Vieira, \& Almeida, 2016). The combined evidence described above suggests that the increase of home care delivery, based on the model of the ICCTs, should guide the political decisions in the health care area.

The fact that this was not a randomly selected sample limited the generalization of the results. The application of the one-year timeframe as the single criterion conditioned the diversity of cases analyzed in each type of care unit, which affects the overall mean scores obtained in the variables under analysis. In the future, studies should use a randomly selected sample, stratified by type of care unit, so as to be representative of the reality of the NNICC at a national level. However, given that this was an initial study on the impact of the care provided by the NNICC, the adopted methodology allowed the production of important and clinically relevant results based on a significant sample that was extended to all types of care. Palliative care units were the only exception due to their specific nature, as well as the fact that this type of care unit does not exist in the area of influence of the Local Coordination Team selected for this study.

\section{Conclusion}

Dependent persons admitted to the NNICC within the period under analysis show a low to moderate potential for the recovery of autonomy. At the time of admission, those patients who are more dependent are older people, with longer time of dependence and hospital length-of-stay, more episodes of disease worsening, a higher level of functional impairment. These patients had a less positive evolution and, at clinical discharge, they were also more dependent.

Despite the differences found in the patterns of dependence and its evolution across the different types of NNICC units, which is expected given the legal criteria for referral, dependent persons showed health gains during their stay, namely the improvement in the levels of functional impairment and self-care dependence.

The results of this study demonstrate that the investment in the NNICC, as one of the pillars of the National Health Service, towards care continuity, can be extremely beneficial for families due to the significant aging of the population and the consequent increase in the number of self-care dependent individuals.

Based on the results of this research study, further studies should be conducted to compare the evolution of dependent persons admitted to the NNICC and Family Health Units. These studies should focus on the same timeframe and use a longitudinal approach, thus allowing for a rigorous assessment of the added value of the NNICC as a health care and social support model.

\section{References}

Administração Central do Sistema de Saúde. (2015). Monitorizaçâo da Rede Nacional de Cuidados Continuados Integrados (RNCCI): $1^{\circ}$ semestre de 2015. Lisboa, Portugal: Autor. 
Conselho Internacional de Enfermeiros. (2005). Classificação internacional para a prática de enfermagem: Versáo 1.0. Lisboa, Portugal: Ordem dos Enfermeiros.

Costa, A. C. (2013). Famílias que integram pessoas dependentes no autocuidado: Estudo exploratório de base populacional no concelho do Lisboa (Doctoral thesis). Retrieved from http://hdl.handle. net/10400.14/13420

Decreto-Lei n. ${ }^{\circ}$ 101/06 de 6 de junho. Diário da República no 109/06 - I Série A. Ministério da Saúde e do Trabalho e da Solidariedade Social. Lisboa, Portugal.

Filipe, M. M. (2015). Contributos para um modelo de contratualizaçâo de cuidados em contexto domiciliário: Estudo exploratório sobre os custos de funcionamento das ECCI (Doctoral thesis). Universidade Católica Portuguesa, Instituto de Ciências da Saúde, Porto, Portugal. Retrieved from http://hdl.handle.net/10400.14/20705

Gonçalves, P. J. (2013). Famílias que integram pessoas dependentes no autocuidado: Estudo exploratório de base populacional no concelho do Porto (Doctoral thesis). Universidade Católica Portuguesa, Retrieved from http://hdl.handle.net/10400.14/18580

Instituto Nacional de Estatística. (2011). Censos de 2011: Resultados definitivos: Portugal. Lisboa, Portugal: Author.

Koç, Z. (2015). The investigation of factors that influence self-care agency and daily life activities among the elderly in the northern region of Turkey. Collegian, 22(3), 251-258. doi: 10.1016/j.colegn.2014.01.002

Machado, M. M., Vieira, M., \& Almeida, S. (2016). Health and self-care profile of older people: A descriptive study in nursing homes, in northern Portugal. Quality in Primary Care, 24(1), 12-16. Retrieved from http://primarycare.imedpub.com/health-andselfcare-profile-of-older-people-a-descriptive-studyin-nursing-homes-in-northern-portugal.pdf

Maciel, E. A. (2013). O potencial de reconstrução da autonomia no autocuidado: Estudo exploratório acerca da sua concretização numa amostra de clientes, três meses após a alta hospitalar (Master's dissertation). Re- trieved from http://hdl.handle.net/10400.26/9453

Observatório Português dos Sistemas de Saúde. (2015). Acesso aos cuidados de saúde.: Um direito em risco?: Relatório de Primavera 2015. Retrieved from http://www.opss.pt/sites/opss.pt/files/RelatorioPrimavera2015.pdf

Paúl, C. (2012). Tendências atuais e desenvolvimentos futuros da gerontologia. In C. Paúl \& Ó. Ribeiro (Eds.), Manual de gerontologia (pp. 1-40). Lisboa, Portugal: LIDEL.

Petronilho, F. A. (2013). A alta hospitalar do doente dependente no autocuidado: Decisóes, destinos, padrōes de assistência e de utilização dos recursos: Estudo exploratório sobre o impacte nas transiçóes do doente e do familiar cuidador (Doctoral thesis). Retrieved from http://repositorio.ul.pt/handle/10451/10572

Petronilho, F. A., Pereira, F. M., \& Silva, A. A. (2017). Evolução e destino das pessoas dependentes no autocuidado: Estudo longitudinal. Revista Investigação em Enfermagem, 18, 33-43.

Ribeiro, O. M., Pinto, C. A., \& Regadas, S. C. (2014). A pessoa dependente no autocuidado: Implicaçóes para a enfermagem. Revista de Enfermagem Referência, 4(1), 25-36. doi: 10.12707/RIII12162

Sacco-Peterson, M., \& Borell, L. (2004). Struggles for autonomy in self-care: The impact of the physical and socio-cultural environment in a longterm care setting. Scandinavian Journal of Caring Sciences, 18(4), 376-386. doi: 10.1111/j.14716712.2004.00292.x

Schumacher, K. L., Stewart, B. J., Archbold, P. G., Dodd, M. J., \& Dibble, S. L. (2000). Family caregiving skill: Development of the concept. Research in Nursing \& Health, 23(3), 191-203. doi: 10.1002/1098-240X(200006)23:33.0.CO;2-B

Shyu, Y. I., Chen, M. C., Chen, S. T., Wang, H. P., \& Shao, J. H. (2008). A family caregiver-oriented discharge planning program for older stroke patients and their family caregivers. Journal of Clinical Nursing, 17(18), 2497-2508. doi: $10.1111 /$ j.1365 2702.2008.02450.x 